\title{
REPRESENTATION PROBLEMS UNDER THE NEW YORK STATE LABOR RELATIONS ACT
}

\author{
Watter P. ARenwald* and Donald M. Landay $†$
}

$7 \mathrm{HE}$ development and administration of a comprehensive system of labor legislation in the state of New York since I937 is a valuable model which deserves more attention than it has yet received. The most important statute in this system is the New York State Labor Relations Act, ${ }^{x}$ enacted in 1937 in order to guarantee to workers employed in industries engaged in commerce within the state of New York the same rights that the National Labor Relations Act guarantees to employees in industries engaged in interstate commerce. ${ }^{2}$

The general objectives of the New York act are: (I) to enable workers to form, join, or assist labor organizations; (2) to provide government machinery for the investigation of questions or controversies concerning representation and for the certification of representatives; and (3) to bind the employer to bargain collectively in good faith with the duly designated representatives of his employees. The terms of the New York act are not identical with those of the Wagner Act, because in enacting the state statute the legislature was able to profit to some extent by the experiences of the National Labor Relations Board. The New York act is administered by the New York State Labor Relations Board, composed of three members appointed by the Governor for terms of six years. At

*A.M., Economics, University of Chicago, I940.

$\dagger$ Assistant Economist, Bureau of Labor Statistics, Department of Labor.

This article is based on material collected by Mr. Arenwald during the summer of 1939 when he was privileged to examine the case files of the New York State Labor Relations Board and to interview members of its staff. Mr. Landay's contributions relate more especially to recent developments. The authors are indebted for many valuable suggestions to Harry A. Millis, Chairman Emeritus of the Department of Economics, University of Chicago, now Chairman of the National Labor Relations Board. The authors alone, however, are responsible for the conclusions reached and the recommendations formulated.

I N.Y. Cons. Laws (McKinney, I940) c. $50, \S 700$ et seq. Further references to the act will be indicated by section citations only.

${ }^{2}$ Section 7 I 5 of the act precludes its application to any employer who agrees with the board that its employees are protected by the National Labor Relations Act. In the absence of such an agreement, the state act may be enforced against employers participating in both interstate and intrastate commerce, at least until the state board's jurisdiction is displaced by the NLRB. Davega City Radio, Inc. v. SLRB, 28x N.Y. I3, 22 N.E. (2d) I45 (r939). 
the time of the formation of the board in July I937, the state was fortunate in obtaining the services as members of three men with previous experience on the staff of the NLRB. ${ }^{3}$ In contrast to the NLRB, the SLRB has been the subject of little unfavorable comment by employers or by the New York State Federation of Labor (AFL), and it has frequently been praised by the State Industrial Council (CIO). More important, it has won the public approbation of a legislative committee appointed to investigate it. ${ }^{4}$ This successful record enhances the value of a study of those policies of the SLRB which have differed considerably from the adversely-criticized corresponding policies of the NLRB.

The first part of this article will attempt to examine and evaluate in the light of three years of experience two significant provisions of the New York act not found in the Wagner Act: the provision for petitions by employers and the craft-unit proviso. The remainder of the article will endeavor to describe the evolution of and evaluate the policy of the SLRB regarding elections to determine the appropriate bargaining unit and its policy regarding the form of ballot employed in elections and run-offs. ${ }^{5}$

\section{THE EMPLÒYER PETITION}

The rules of the SLRB, like those of the NLRB, provide for the initiation of representation proceedings by the filing of petitions requesting the board to make an investigation and to certify the representatives designated by the employees for the purposes of collective bargaining. Neither board has ever questioned the right of an employee or of any person or labor organization acting on behalf of employees to file a petition; in fact a vast majority of the representation cases have been initiated by employee petitions. In certain unusual situations, however, the employer desires to initiate board proceedings at a time when none of the labor

3 Dr. John P. Boland, chairman, Paul M. Herzog, and John D. Moore. In January I94r, George I. Cassidy, an editorial writer of the New York Post, was appointed to fill the vacancy caused by the death of Mr. Moore. During 1937 the board had a staff of 23 persons, which was increased to 52 in 1938 and 69 in 1939.

4 Report of the New York State Joint Legislative Committee on Industrial and Labor Relations, Legislative Doc. No. 57, at 23 (1940).

5 The present article thus deals with but a part of the board's activities, that concerned with representation. For a description of cooperative action by the SLRB and the New York State Board of Mediation see Arenwald, Mediation, Arbitration, and Investigation of Industrial Disputes in New York State, I937-40, 49 J. of Pol. Econ. 59 (I94x). A more comprehensive discussion of the activities of these two boards is to be found in Arenwald, Labor Relations Legislation and its Administration in New York State, I937-r939 (unpublished manuscript, r940), which is available in the libraries of the SLRB, the NLRB, and the University of Chicago. 
organizations involved is sufficiently confident of commanding a majority to file a petition. Although nothing in the Wagner Act forbids the extension to employers of the right to petition, during the first four years of its history the NLRB refused to grant this right to employers. This refusal was interpreted by unfriendly critics as evidence that the act was onesided and that the board was biased in favor of unions. Such adverse criticism was probably in large measure responsible for the issuance on July II, I939, of new rules permitting employers to file petitions which, however, must contain

a brief statement setting forth that a question or controversy affecting commerce has arisen concerning the representation of employees in that two or more such labor organizations have presented to the employer conflicting claims that each represents a majority of the employees in the unit or units set forth above. ... .6

When the New York legislature enacted the State Labor Relations Act in May I937, it was able to estimate the significance of this problem, and the state act, by authorizing the board to proceed upon an employer's allegation that there is a question or controversy concerning representation, confers upon employers the right to petition. The rules of the SLRB have at all times permitted an employer to petition even when but one union claims to represent a majority of the employees.

Throughout the history of the SLRB, however, restrictions have been imposed upon employers to prevent abuse of their right to petition. During the first two years there was a significant difference between the provision authorizing the board to act upon an employer petition and that authorizing it to act upon an employee petition. The original terminology provided that:

Whenever it is alleged by an employee or his representative that there is a question or controversy concerning the representation of employees, the board shall investigate such question or controversy and certify in writing to all persons concerned the name or names of the representatives who have been designated or selected. Whenever it is alleged by an employer or his representative that there is a question or controversy concerning the representation of employees, the board may investigate such question or controversy after a public hearing held upon due notice.7

At the outset the SLRB interpreted the difference between "shall" and "may" as authorizing the adoption of a general policy of conservatism in deciding whether or not to proceed with an investigation when petitioned by an employer. The proviso that upon an employer petition the board's investigation shall follow a public hearing after due notice has no special

6 National Labor Relations Board, Rules and Regulations (Series 2, as amended, March Ir, 1940) $\S 203.2 \mathrm{~b}(5)$.

7 § 705(3) (italics added). 
significance, because this requirement has been construed by the board to apply to both employer and employee petitions, and the board has not proceeded formally with any petition except with the consent of the parties.

In the interest of justice to employers caught between conflicting claims of rival labor unions, the Ives Committee recommended that the legislature make it mandatory for the board to investigate all cases initiated by employer petitions. ${ }^{8}$ Consequently in April 1940, the act was amended by changing "may" to "shall" in the sentence authorizing action upon employer petitions. 9 This amendment has probably not caused any significant alteration in the methods developed by the board for handling employer petitions. ${ }^{\text {Io }}$

A significant restriction upon the right of employers to petition is imposed by the provision in the act that "no election shall be directed by the board solely because of the request of the employer or of the employees prompted thereto by their employer." In the Interborough Fur Storage Co. case $^{\mathrm{x}_{2}}$ the board indicated its attitude regarding the extent of this limitation. In that case both the Fur Merchants Union and the Independent Cold Storage Workers Union claimed to represent a majority of the employees, but only the employer filed a petition. The board found:

Counsel for the Independent stated that that organization desired to have the Board proceed with its investigation in this matter. The Direction of Election herein is, therefore, not "solely because of the request of the employer" and not within the prohibition of Section 705(4) of the Act. The claim of counsel for the Fur Merchants Union that the Board should not exercise its jurisdiction in the premises is without merit, and his motion in that respect has accordingly been denied. ${ }^{3}$

${ }^{8}$ Report of the New York State Joint Legislative Committee on Industrial and Labor Relations, Legislative Doc. No. 57, at 24-25 (r940).

9 § 705 (3), amended by N.Y.L. (I940), c. 750.

so The increase in the proportion of employer petitions from 5 per cent of all petitions filed in the fiscal year I939-40 to 9 per cent in the last six months of 1940 might, at least in part, be attributed to this amendment. See notes $I_{4}$ and $I_{5}$ infra.

II $\S 705(4)$.

${ }^{22}$ SEE-2894, Decision No. 572 (June 30, 1939). The board has adopted a system of classifying its cases according to regions and types. The first letter which precedes the case number $(S, C$, or $W$ ) indicates whether the case arose in the southern, central, or western region of New York. The following letter or letters indicate the type of case. U stands for "unfair" and indicates an unfair labor practice. E stands for "election" and indicates a representation case which was initiated by an employee petition. EE stands for "employer election" and indicates a representation case which was initiated by an employer petition. In each region the cases are numbered consecutively in the order in which the petitions and charges are received.

${ }_{3}$ SEE-2894, Decision No. 572, at 3 (June 30 , x939). 
The direction of an election in this case shows that the board believes that it can hold an election at the request of an employer if, and only if, at least one of the labor organizations involved indicates a desire for an investigation.

A striking aspect of the SLRB's experience is the fact that so few employer petitions have been filed. During the first 32 months of the board's history (July I, I937 to March I, I940) 2,962 petitions were filed by unions and only $\mathrm{II}_{3}$ by employers, the latter thus constituting but 3.35 per cent. ${ }^{14}$ Of these II 3 cases, 44 involved controversies between an AFL and a CIO union, 25 involved an AFL or a CIO affiliate and an independent union, one was a dispute among an AFL, a CIO, and an independent union, and the remaining 43 involved only one union. ${ }^{55}$

Informal conferences have revealed that many employers are unaware of their right to petition the state board. This may be due to the publicity given the NLRB's original refusal to accept employer petitions, or it may be that many employers have considered any labor board to be inevitably biased, and rather than to call for intervention by an agency which might discover unfair labor practices or compel genuine collective bargaining, they have preferred to risk the consequences of allowing a representation controversy to take its course. The dearth of employer petitions under the New York act indicates that the denial of the right to petition has probably not been a bona fide grievance against the Wagner Act and the NLRB. ${ }^{x}$ But since employers are prima facie denied a right granted to employees, the battle cry of discrimination has an apparent justification and has served as a convenient wedge to open the way for more drastic proposals which would effectively cripple the NLRB and nullify the Wagner Act.

The employer petition cases are of two types, those involving only one

34 During the ten months from March I to December 3r, I940, an additional 862 petitions were filed by unions and $5 \mathrm{r}$ by employers. The proportion of employer petitions has thus increased slightly, amounting during the first forty-two months of the board's history to 4.3 per cent.

15 Seven of the additional $5 \mathrm{I}$ cases filed between March I, I940 and December 3I, I940 involved claims to representation by both CIO and AFL affiliates, 9 involved either an AFL or CIO affiliate and an independent union, and 35 involved only one union. The large increase in single-union cases may in part be attributed to the amendment of $\$ 705(3)$ which became effective in April 1940. See note 9 supra.

${ }^{16}$ Despite the assertion of the Smith Committee investigating the NLRB that "the restrictions placed about the submission of such employer petitions were extremely onerous," the present authors believe that the lack of a real need for employer petitions almost fully explains the filing of but one such petition by March 4, I940. See Final Report of the House of Representatives Committee to Investigate the NLRB 470-7I, 76th Cong. Ist Sess. (Bureau of Nat'l Affairs, Dec. 28, 1940). 
union, and a second group involving two or more unions. In one group of single-union cases the employer seeks an election before completion or the union's organizing campaign in order to damage the prestige of the union by proving that it does not represent a majority, and thus to avoid a certification obligating him to bargain collectively. Fear of the problems involved in this situation was apparently responsible for the NLRB's refusal to accept any employer petitions prior to July 14, I939, and for its present refusal to accept such petitions in cases involving only one union. The first step of the SLRB in these cases has been to ascertain in the informal conference stage whether or not the union will consent to an election or card comparison. The SLRB has exercised great tact in cases where the refusal of the union to consent has made the direction of an election impossible since the proceedings would be "solely because of the request of the employer." The SLRB has never disposed of a singleunion case by issuing a formal decision, ${ }^{17}$ for it believes that an informal letter explaining that it has no power to proceed creates a more favorable impression and avoids unfavorable publicity. Files of the SLRB indicate that following the initial informal conferences many such cases have been allowed to remain open but inactive for many weeks and even months, apparently with the intention of letting them die of old age, a result which has been frequently achieved. ${ }^{18}$ Although this dilatory procedure might have dangerous consequences if applied generally, it has proved an effective device for protecting organizing campaigns from employer interference.

In some of these single-union cases employers have filed petitions in the hope that following defeat of the union in an election they might obtain injunctions restraining picketing. For the first two and one-half years of the board's existence, the decision in the Crareford Clothes case ${ }^{\mathrm{x}}$ seemed to

I7 The board took formal action on only I8 of the II 3 employer petitions filed during the first thirty-two months. The success of the SLRB in informally settling so many cases initiated by employer petitions is in line with its record of settling without resort to formal action 9 r.4 per cent of the 6,045 cases submitted to it during the first three and one-half years.

${ }^{18}$ Examples are New Amsterdam Laundry (SEE-3356) and Albany Public Market (CEE50).

If the Smith Committee investigating the NLRB had made a more careful analysis of "the deliberate use of dilatory methods" by the board it might have found that these tactics promoted conciliation and mediation rather than that they "induced and protracted a large number of industrial disputes." See Report, op. cit. supra note 16 , at 496.

I9 Crawford Clothes, Inc. v. Frankel, 98 N.Y.L.J. 637 (S. Ct., Sept. Ir, 1937). In this case an AFL union which had lost an SLRB election picketed while the employer negotiated a contract with the CIO union. Justice Poletti held that a labor dispute existed within the meaning of the New York State "Norris-LaGuardia" act and refused to grant an injunction. Cf. Stalban v. Friedman, 259 App. Div. 520, x9 N.Y.S. (2d) 978 (I940). 
indicate that the courts would probably refuse to enjoin picketing by a union which had lost an SLRB election. ${ }^{20}$ On the basis of this precedent the SLRB effectively discouraged some employers who informally inquired concerning their right to petition.

In addition to quashing employer petitions brought to damage the prestige of a union, the SLRB has closed many other single-union cases in which it lacked the power to take formal action, because the employer alone had requested proceedings. In nine of the forty-three cases the filing of an employer petition has led to an informal conference culminating in a general understanding as to settlement of the controversy. The provision for employer petitions is thus a valuable device for obtaining speedy submission of such disputes to an impartial government agency. In each of these nine cases (as well as in four others where some agreement was reached by direct negotiations between the parties while the board held the case in abeyance) the employer subsequently withdrew his petition. The board closed four other single-union cases by sending informal letters of dismissal to the parties, and in two cases informal conferences resulted in agreements for consent elections.

Moreover, in eleven of these forty-three cases the union and the employer at all times agreed that the union did not represent a majority of the employees. There being no question or controversy concerning representation, the board could not proceed formally, and all of these cases were closed by withdrawal or dismissal of the petition. Four are of special interest, however, because they arose out of attempts by unions to organize employers rather than employees. ${ }^{2 x}$ By "organizing employers rather than employees" is meant the tactic of compelling the employer to sign a closed-shop contract regardless of how few of his employees are union members. If the employer refuses to sign, the union pickets the

${ }^{20}$ In Euclid Candy Co., Inc. v. Summa, I74 Misc. I9, I9 N.Y.S. (2d) 382 (S. Ct. 1940), Justice Daly declared that there was no labor dispute within the meaning of the anti-injunction act because the labor dispute terminated with the certification of the independent union by the NLRB. An injunction was therefore granted restraining the AFL union which lost the election from picketing the employer to induce him to break his closed-shop contract with the independent union. This decision was affirmed without opinion by the appellate division, second department, in 259 App. Div. I08r, 2r N.Y.S. (2d) 6r4 (1940). It was followed by the lower court in Kings County in Florsheim Shoe Store Co., Inc. v. Retail Shoe Salesmen's Union of Brooklyn and Queens, Local 287, I04 N.Y.L.J. 2189 (S. Ct., Dec. 24, r940). Thus the doctrine applied by the appellate division in the second department is the opposite of that applied by the appellate division in the first department. As yet no case has been taken to the court of appeals, and the law therefore remains unsettled.

${ }_{2 x}$ Morris Lunch (CEE-77); Famous Lunch Bar (CEE-46); Lynn's Food Shops (SEE-3050); and George Kern \& Son, Inc. (SEE-r 743, SEE-3665). 
plant. If the employer signs, the union may have succeeded in "organiz ing" the establishment without troubling to persuade a single employee of the advantages of joining the union.

Because it could find no question or controversy concerning representation and because any election would have been "solely at the request of the employer," the board could not proceed formally, but could only hold these cases in abeyance. In two the employers finally yielded to the pressure of the picket line and signed closed-shop contracts, and in one the employer withdrew his petition and negotiated directly with the union. In the remaining case the employer went out of business, but there is no evidence that the dilatory tactics of the board were primarily responsible for this result.

The problem of policy presented by the tactic of "organizing employers rather than employees" was most clearly revealed in the George Kern case. ${ }^{22}$ There a union which frankly admitted that it represented none of his employees, eventually compelled a meat packer to sign a closedshop contract by picketing at the points of retail distribution. The employer petitioned the SLRB because of fear that if he signed a closedshop contract he would be committing an unfair labor practice, ${ }^{23}$ and the union responded that it was merely protecting existing contracts with the majority of the other employers in the industry. In the opinion of the authors, a union is justified in picketing in an attempt to induce a majority of the employees in a shop to join it. But there should be some restraint upon picketing which is designed to induce consumers to refrain from purchasing the employer's product and thus to compel him to sign a closed-shop or exclusive bargaining contract which imposes collective bargaining upon employees who do not desire it. In order to have stable, democratically-controlled unions, employees must be educated to the value of collective bargaining. They must not be coerced into collective action. In the Kern case, therefore, the union should have been compelled to confine its picketing to the manufacturer's plant.

The SLRB might be able to discourage "organizing employers rather than employees" by directing an election in such a situation and then, on the basis of that precedent, by threatening elections if the unions persist in demanding closed-shop contracts and yet fail to attempt seriously to organize the employees. To adopt this policy, the board would have to interpret more liberally the statutory authorization of employer petitions. If adequate evidence were submitted by either the employer or the individual employees showing that a substantial number of employees did not

$$
{ }^{22} \text { SEE-I743, SEE-3665. }
$$$$
{ }_{23} \S 704(5) \text {. }
$$ 
desire to be represented by the union but did desire an election, the board might find that, although the union refused to consent, an election would not be "solely at the request of the employer."

The second major group of employer petition cases involves two or more unions. A question or controversy concerning representation may or may not exist. In general the SLRB has handled more expeditiously cases in which a real representation question arose than any other type of case initiated by an employer petition. It has attempted to grant quick relief to petitioning employers "caught in the middle" of a genuine representation controversy.

The employer's right to petition has proved particularly valuable in these cases because the filing of a petition has frequently resulted in bringing representatives of all parties together for the first time. In an informal conference at the board's offices an examiner prepared to act as a mediator will first attempt to obtain the consent of all parties to an election. In five of the seventy employer petition cases involving more than one union which were filed between July I, I937 and March I, I940, stipulations for consent elections were signed. ${ }^{24}$ More impressive is the fact that in at least fourteen other cases a general settlement of the controversy was reached during or after the board's informal conference. ${ }^{25}$ Three employer petitions were dismissed upon the board's finding that it lacked jurisdiction because a substantial element of interstate commerce was involved, and another two were informally dismissed for non-prosecution. That the SLRB found it necessary to direct elections in only five of these cases reveals its striking success in achieving informal settlements. ${ }^{26}$

${ }_{24}^{24}$ Quality Laundry Service, Inc. (SEE-2II); Bristol Pharmacy, Inc. (SEE-596); Westmore Restaurant (SEE-393I); Yonkers New System Laundry (SEE-3994); and Payman Drugs, Inc. (SEE-472I).

${ }^{25}$ In each of these cases the petition was subsequently withdrawn by the employer or was dismissed by informal letters after the controversy had been settled without an election or card comparison.

${ }^{26}$ Interborough Fur Storage (SEE-2894, Decision No. 572, June 30, I939); Varick Machine and Tool Works, Inc. (SEE-I2II, Decision No. 227, Aug. 29, I938); Precision Inductance Corp. (SEE-ror3, Decision No. 274, Feb. 23, r938); and Knickerbocker Laundries (SEE-378, Decision No. 93, Feb. $x \mathrm{I}, \mathrm{I93}$ ). In all except the first case, discussed above at p. 474, petitions were also filed by one or more of the labor organizations involved. The board subsequently dismissed the petitions in the Square Transportation case because the employer had gone out of business. Decision No. 274-B (Oct. 24, 1938). No election was actually held in Knickerbocker Laundries because the eleventh hour withdrawal of the AFL union made it possible to settle the matter by means of a card comparison.

The SLRB has successfully cooperated with the state Board of Mediation to facilitate voluntary settlements. Arenwald, Mediation, Arbitration, and Investigation of Industrial Disputes in New York State, I937-40, 49 J. of Pol. Econ. 59, 76 (I94I). 
The SLRB is without power to aid the employer where no question or controversy concerning representation exists. ${ }^{27}$ In such cases the board has no authority to act regardless of whether the petition was filed by an employer or by a labor organization. In Kanter Department Stores, Inc. ${ }^{28}$ Morganthau Seixies Co., ${ }^{29}$ and Nostrand Service Stations, ${ }^{30}$ it dismissed union petitions when the employer conceded the petitioning union's claim that it represented a majority of the employees. In these three cases the operation of this restriction upon the board's investigatory powers involved no problem of public policy. But a serious problem of public policy is raised when this same restriction operates against a harassed employer seeking the aid of the board. An employer trying to maintain an existing collective bargaining relationship with the union representing a majority of his employees may be confronted by another union which, while admitting that it does not represent a majority, pickets his products and exerts other forms of direct pressure in an attempt to compel him to break his existing contract and negotiate with it. The press has failed to understand that the SLRB, as well as the NLRB, has no power to proceed formally in such cases, and as a result the labor boards are accused of being biased and of granting relief to unions while remaining indifferent to the fate of employers. In fact, the board has accorded the same consideration to employer petitions in these cases that it has granted to petitions filed by unions, and has delayed dismissing petitions in order to encourage direct negotiations or attempt mediation in informal conferences. This virtual identity of treatment is well illustrated by the fact that in the Old Russian Bear case, ${ }^{3 \mathrm{I}}$ both an employer's petition and a union's petition based on the same set of facts were dismissed because the board found no question or controversy concerning representation. Nevertheless, the fact that the board has been obliged to dismiss some of these cases before a settlement has been reached shows that the right of employers to petition is not a completely adequate device for protecting in this situation the rights of employers and employees and for maintaining industrial peace. ${ }^{32}$

$27 \S 705(3)$.

${ }^{28}$ SE-86 and SU-86A, Decision No. 9o (Feb. Ir, I938).

${ }^{29} \mathrm{SE}-700$, Decision No. I75 (June I4, I938).

${ }^{30} \mathrm{SE}-9 \mathrm{I} 3$, Decision No. 55 (May I8, I938).

${ }^{3 x} \mathrm{SEE}-2592, \mathrm{SE}-2646$. In three other cases the basis for an agreement was established at informal conferences; two others were settled by direct negotiation and the employers' petitions were withdrawn.

${ }^{32}$ The only case in which the board issued a formal decision dismissing the employer's petition was that of Yoshio Mita, doing business as O. \& K. Sandwich Shop (SEE-4253, SE- 
There are much more cogent reasons for preventing picketing by a minority union during the life of a certification or contract than for abolishing it in the special types of single-union cases previously discussed. While the objective of picketing in the single-union cases is to extend collective bargaining, although at a time when the majority of employees within the particular unit do not desire it, the objective of minority union picketing in a case involving more than one union is to destroy the existing system of collective bargaining supported by the majority of the employees in the unit and to substitute for it a new and different system. The ideal of collective bargaining is a system of representative government in industry. To this end the state should discourage replacement by employees within a particular unit of one system of industrial government by another. Democracy within unions should be fostered; employees should be encouraged to change union policy to meet changing needs by activity within the union rather than by secession and formation of a new union. ${ }^{33}$

Moreover, an employer who is obeying the letter and spirit of the labor relations acts by bargaining collectively with the union representing the majority of his employees should be encouraged to continue to do so by protection against attacks by other unions. Certainly it is illogical for the state to impose upon the employer the obligation to bargain collectively with representatives of the majority of his employees, to give that majority the right to bargain collectively through delegates of their own

4575, Decision No. 777, June 9, 1940). In the Barry (SEE-1370) and Old Russian Bear (SEE2592, SE-2646) cases the employers' petitions were eventually dismissed by informal letters. The need for legislative action to furnish some protection was emphasized when the appellate division voided an injunction against picketing by the minority union which had been granted by a lower court in the Old Russian Bear case. The court ruled unanimously that a labor dispute within the meaning of the New York state "Norris-LaGuardia" act existed and that an anti-picketing injunction was therefore barred. Stalban v. Friedman, 259 App. Div. 520, I9 N.Y.S. (2d) 978 (1940). Cf. note I9 supra. The two opposing lines of decisions discussed in notes $x g$ and 20 supra indicate that the law in New York on this point is not yet settled. Two recent decisions by the United States Supreme Court appear to support the view that cases of this type involve a labor dispute within the meaning of the federal Norris-LaGuardia Act and that minority union picketing should not be enjoined. United States v. Hutcheson, 6r S. Ct. 463 (194I), and AFL v. Swing, 6I S. Ct. 568 (I94I). For the reasons indicated below the authors believe that the law on this question should be settled by an amendment to the New York State Labor Relations Act.

${ }_{33}$ It might be argued, however, that employees can more effectively maintain democracy within their union if they are at all times in a position to threaten to secede from it and enter a rival union. But is it the best method of developing stable and democratic machinery to encourage each group to threaten to abandon the union if its particular desires are not immediately satisfied? 
choosing, and then to allow actions, presumably legal, by third parties designed to coerce the employer, upon whom the obligation has been placed, and to destroy the majority's right which the state itself has created.

Minority-union picketing might be eliminated by amendment of the New York State Anti-Labor Injunction Act ${ }^{34}$ to facilitate the granting of injunctions in such situations. But it would not be sound public policy to suspend the procedural safeguards of this act upon the mere allegation of an employer that picketing was being carried on by a minority union. A better device would be an amendment to the State Labor Relations Act. It should define as an unfair practice picketing to compel an employer to break his contract with a union conceded by all parties to be the representative of the majority of the employees within the appropriate unit or certified as such by the board less than one year previously. The amendment should also give the SLRB power to issue a cease and desist order upon finding that such picketing was in progress. This provision would guarantee the union a public hearing before an administrative tribunal with special qualifications in handling labor disputes. During the winter of $x 940$ a bill authorizing the board to issue cease and desist orders against picketing by minority unions during the life of a certification was introduced into the Legislature on the recommendation of the Ives Committee..$^{35}$ Because both the State Federation of Labor and the State Industrial Council feared that it would constitute a dangerous encroachment upon labor's right to picket and because certain employers felt that it would give too much power to the board, the measure never reached the floor of the Senate.

The major contention of opponents of any restriction on minority union picketing is that picketing is a method of expressing opinions and publicizing the facts of a dispute and that consequently any limitation of this right would be a dangerous encroachment upon the right of free speech. ${ }^{36}$ This contention fails to recognize that picketing is now more than a form of self-expression. Limitations of space make it impossible for the union

\footnotetext{
${ }^{34}$ N.Y. Civ. Prac. Ann. (Gilbert-Bliss, Supp. I940) $\$ 876$ a (the New York state "NorrisLaGuardia" act).

35 Senate Introductory No. 922 (I940). See discussion in report of the New York State

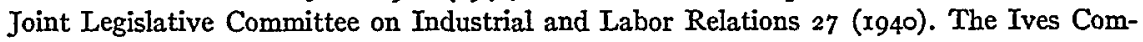
mittee failed to deal with the larger problem of eliminating picketing where all parties' agree that the union holding the contract represents the majority.

${ }^{36}$ This argument has been ably presented in The Labor Injunction under NLRA, 8 Int'I Juridical Ass'n Bull, 44-49 (I939). For another criticism of proposals to restrict minority union picketing, see Padway, The Norris-LaGuardia Act and National Labor Relations Act, 2 Nat'l Lawyers' Guild Q. 227-45 (r940).
} 
to present with signs an adequate statement of its case and for the employer to reply adequately by placing signs in the windows of his establishment. Moreover, it is difficult for the consumer to ascertain the true facts and merits of the case from these conflicting condensed versions. Consequently a large section of the consuming public refuses as a matter of policy to cross any picket line, regardless of the contentions of the disputing parties.

Most picketing in the service industries (which constitute the largest area of the SLRB's jurisdiction) is designed to coerce the employer by persuading potential customers not to patronize his establishment. The strength of such picketing as a weapon in no way varies with the merits of the union's position. Stability of collective bargaining requires that the use of this weapon by a minority union be eliminated. In developing a sound public policy respecting picketing and free speech (as well as in defining Henry Ford's right to freedom of speech when addressing his employees), it is essential to draw "the line between speech as a device to persuade and speech as a device to exercise authority; speech as an innocent, friendly communication (though between employer and employee) and speech as the exertion of power." ${ }_{37}$

The difficulties faced by the SLRB in employer petition cases should not obscure the fact that only I64 employer petitions were filed during the first forty-two months of the board's history and that the administrative problems of sifting thousands of such petitions, long feared by the NLRB and anticipated by the SLRB, have never materialized. Nor has it been difficult to weed out and effectively dispose of those few petitions filed to obtain premature elections before the unions could complete their organizing campaigns.

\section{THE CRAFT-UNIT PROVISO}

In the campaign to amend the National Labor Relations Act much attention has been focussed upon various proposals to limit the discretion of the NLRB in determining the appropriate unit in order to "protect the rights of craft groups." The AFL has supported such proposals on the ground that the NLRB has disregarded the special interests of craft groups and has discriminated against the AFL in favor of the CIO. Since the CIO organizes on industrial lines, it is usually able to defeat the AFL in an election held within an industrial unit.

The AFL at first supported the Walsh bill which provided: "That when a craft exists, composed of one or more employees, then such craft

37 Greene, Civil Liberties and the NLRB, 8 Int'I Juridical Ass'n Bull. Io0 (I940). 
shall constitute a unit appropriate for the purpose of collective bargaining for such employee or employees; a majority of such craft employees may designate a representative for such unit. ...". ${ }^{8}$ Subsequently the AFL endorsed the slightly different formulation of the proviso in the Norton bill, namely, "That in any case where the majority of employees of a particular craft shall so decide the Board shall designate such craft as a unit appropriate for the purpose of collective bargaining." 39 Thus it would be mandatory for the board to determine whether a majority of employees in the craft unit desired to bargain as a separate unit and by which union, if any, they desired to be represented. The New York act contains an identical provision, ${ }^{40}$ which was included primarily because of the influence exerted by the New York State Federation of Labor. The AFL, however, might not so readily endorse the Norton or Smith bills were it to realize that the New York craft-unit proviso has done as much to thwart the organizing efforts of the AFL as to aid them.

In the very first case in which the craft-unit proviso was a factor, this proviso was invoked by an employer in opposition to the claims of an AFL union. In the Rockefeller Center Corp. case ${ }^{4 x}$ the International Brotherhood of Electrical Workers filed a petition for certification as the collective bargaining agent for a unit composed of elevator maintenance men, plumbers, steam fitters, sheet metal workers, refrigeration men, and machinists, as well as the electricians. The employer feared that there would be subsequent jurisdictional disputes if the IBEW were certified as rep-

${ }^{38} \mathrm{~S} .1000,76$ th Cong. Ist Sess. (I939).

39 H.R. 9195, 76th Cong. 3d Sess. (I940). See 6 Lab. Rel. Rep. $22_{2}$ (1940); N.Y. Times, col. 2, p. I (April 4, 1940).

On June 7, I940 the House of Representatives passed the Smith bill after incorporating in it at the behest of the AFL the following amendment to $\S 9$ of the NLRA: "Whenever in a proceeding under this section it is proposed.... (3) to include employees of a particular employer or employers in any craft in a bargaining unit containing employees other than employees in such craft; the Board shall take a secret ballot .... of the employees in such craft .... for the purpose of determining whether such employees desire to be so included. If a majority of the employees voting vote to be so included, the Board may by order include such employees in a bargaining unit .... containing employees other than employees in such craft. . ... If a majority of the employees voting vote not to be so included, the Board shall by order designate.... the employees in such craft .... as a separate bargaining unit." H.R. 9195, 76th Cong. 3 d Sess. (I940). The bill was not passed by the Senate and so died with the expiration of the Congress. A similar bill will, in all probability, be introduced into the present Congress. Had this amendment been enacted, the board could have ascertained the desires of the employees with regard to the bargaining unit only by means of an election. The Norton bill, on the other hand, did not specify the method for determining whether the majority of the employees desired to bargain as a separate unit in its original proposal on the unit.

$10 \S 705(2)$. 
resentative for all these workers. Consequently both the employer and an "Independent" union invoked the craft-unit proviso to justify the contention that the board ought to direct separate elections for the (I) electricians, (2) elevator maintenance men, and (3) mechanical employees. The "Independent" submitted a petition which allegedly had been signed by a majority of the employees in the electrical craft at Rockefeller Center, requesting the board to declare the electrical department an appropriate unit for collective bargaining. The IBEW apparently became convinced during the course of the hearings that the board would find that the craft was the appropriate unit, for it signed a stipulation recognizing this and providing for three separate elections. It therefore became unnecessary for the board formally to decide the unit question. The results of these elections appear anomalous to anyone who has accepted at face value the professions of faith in craft unionism made by certain AFL leaders. In the elevator maintenance division 3 I employees voted for the IBEW and 9 against; in the mechanical maintenance division $35 \mathrm{em}-$ ployees voted for the IBEW and 3 against; but in the electrical division the IBEW was defeated 26 to I5. In this case not only did an important AFL "craft" union organize into what was virtually an industrial unit workers in crafts only remotely related to it, but it succeeded in organizing employees of these other crafts even though it failed to organize those within its own craft. The IBEW may have contended that a broader unit was appropriate because it anticipated the result, for had the board included all the workers within a single unit, the IBEW would have won that single election 81 to 38 and would have been certified as collective bargaining agent for the electrical workers as well as the elevator maintenance and mechanical maintenance employees..$^{42}$

In several other cases the craft-unit proviso has been used for another purpose very different from that intended by AFL leaders. In the Saks $\& \mathrm{Co}$ case $^{43}$ a local of the International Ladies' Garment Workers Union (then an independent industrial union) contended that since the tailors in the alteration, ready-to-wear, and special order departments of a large department store had decided to bargain as a separate craft, it was mandatory for the board to designate it as the appropriate unit. At a formal hearing the union introduced testimony that at a union meeting a major-

$4^{2}$ The Rockefeller Center case is not unique. In the Fred F. French case (SE-3049) the employer contended at an informal conference that the unit the IBEW sought to represent was not appropriate because it included five unrelated crafts, four of which did not come under the jurisdiction of the electrical workers. This case, however, was eventually dismissed for non-prosecution.

43 SE-3735. 
ity of the tailors had decided to bargain separately. Since the IIGWU was the only union attempting to organize the employees in these three departments, the tailors had no cause to fear that they would be included in a larger unit. Consequently it seems likely that the $\Pi$ LGWU endeavored to employ the craft-unit proviso to convince the board that a smaller unit of about 75 employees (in which it happened to command a majority) was appropriate and that the total of 360 employees in the three departments did not constitute an appropriate unit. ${ }^{44}$ Thus while an industrial union contended that a craft unit was appropriate, the employer insisted upon the industrial unit, that is, a unit consisting of the three departments. The board found:

A careful analysis of the entire record with respect to the craft question reveals insufficient evidence to permit the Board to resolve the issue in favor of either of the conflicting contentions. While the record might permit a finding that there is, generally speaking, a group of skilled handicraftsmen known as tailors, the difficulty arises in defining the artisans employed by this particular company who are entitled to be a part of the group. The testimony shows that the Saks tailors do pressing and finishing work. It also shows that persons employed as drapers do tailoring work. It shows further that the distinction between the type of garments worked on by drapers and tailors is so tenuous as to be without real difference. ....

Since for the purposes of the craft contention, we are unable to find, one way or the other, whether the employees in this case listed as tailors are by themselves a craft, the testimony relating to the union meeting of May and on the issue of whether a majority of the tailors decided to bargain as a craft becomes irrelevant in the present connection. 45

Applying the usual criteria for determination of the unit question the SLRB found that, although a unit composed exclusively of tailors did not constitute a craft unit, it did constitute a unit appropriate for the purposes of collective bargaining. On the basis of union cards and payroll receipts submitted at the hearing it certified the $\Pi G W U$ local as the representative of the tailors.

This commendable decision clearly reveals that the essential difficulty is to determine which workers within a particular shop constitute a craft. What is a craft? Can we be more precise than to say that it is "any

44 In opposing the claim of Luncheonette Employees Union in the Times Square Restaurant, Inc. case (SE-3349) that the kitchen employees and soda-fountain employees constituted a single craft and consequently should be designated as an appropriate unit, the employer contended that this AFL local was in fact an industrial union and that it was seeking a smaller unit in this case only because it did not feel confident of obtaining a majority of the votes of all the employees in the establishment. The board subsequently found that the kitchen employees and the soda-fountain employees constituted two separate units and ordered an election in each unit.

${ }_{45}$ SE-3735, Decision No. 64I, at 4 (Aug. 9, I939). 
group of men performing similar work?" The difficulty of determining which employees in a given shop should be included within a single craft diminishes the danger that the board will frequently be compelled by invocation of the craft-unit proviso to designate a unit in which the union invoking the proviso happens to command a majority rather than the appropriate unit in the light of sound public policy. On the other hand, since this difficulty increases the complexity of the board's task in the administration of the statute, it constitutes a major disadvantage of the proviso. Thus there is reason to believe that inclusion of a similar proviso in the Wagner Act would greatly increase the difficulties of administration.

It is significant that the craft-unit proviso in the New York act has seldom been invoked. The files of the SLRB reveal only ten cases in which the proviso definitely was a factor. Even if the application of the proviso was discussed in other cases in the informal conference stage, the total is a mere handful in comparison with the 3,075 representation cases filed between July $x$, I937 and March I, I940. One reason may be that conflicts concerning the "rights of craft groups" occur less frequently in the service industries which constitute a large part of the jurisdiction of the SLRB than in mass production manufacturing industries employing small groups of skilled craftsmen and large numbers of unskilled production workers..$^{4^{6}}$ Further, the conflict between the AFL and the CIO has not been severe in industries within the jurisdiction of the SLRB.

Another explanation may be that unions which, while originally craft organizations, have in recent years been organizing workers of many different crafts virtually on an industrial basis and have been rendering only lip service to the principles of craft unionism, have realized that the proviso can operate to their disadvantage as well as to their advantage. In some cases it is to the advantage of such "craft" unions to invoke the proviso either to prevent inclusion of a small group of its members within a larger unit in which a competing union commands a majority, or to persuade the board that a unit in which it happens to command a majority is

\footnotetext{
46 "Of the total number of elections and comparison cases from July $\mathrm{x}, \mathrm{x} 937$, to June 30 , I939, combined, I9o were in service industries such as hotels, restaurants, laundries, automobile service, etc., I 67 were among service employees in office and apartment buildings (real estate), 54 in manufacturing, 44 in transportation, ten among employees in architects' offices and private hospitals (professional service), seven in utilities, three in insurance and one each among crushed stone production workers (mining and quarrying) and janitorial employees in public schools (custodial service). Of the 78,725 workers involved in these cases, 47.5 per cent were in the various service industries, 22.9 per cent in transportation, and 20.1 per cent in retail restablishments." Goldberg, Elections and Certifications of Labor Organizations Conducted by the New York State Labor Relations Board, July I, x937, to June 30 , I939, at 7-8 (1939).
} 
appropriate. 47 In other cases the same union may organize along industrial lines. If the union claims representation as a craft in the former type of case, the precedent and the definition of the craft which the board establishes may embarrass that same "craft" union in a case where it has organized vertically. Consequently the union may refrain from invoking the proviso in cases of the first type. At least one union has actually been involved in cases of both types. In the Rockefeller Center case the craft-unit proviso was instrumental in preventing the IBEW local from obtaining certification as representative of what amounted to an industrial unit, but in the Waldorf-Astoria case $^{48}$ the same local contended that a craft unit consisting of $\mathrm{I} 7$ electricians and helpers was appropriate. In that case the employer opposed the designation of $I 7$ of its 2,707 employees as an appropriate unit, contending that it would open the way to the establishment of " 342 different particular crafts conceivably represented by as many labor organizations" and that this result would make impossible harmonious operation of the hotel. The decision is especially significant because the board based its finding that the electricians and their helpers constituted an appropriate unit in part upon the fact that the union's jurisdiction was no broader than the unit it sought.

Because it has been a factor in so few cases, the leaders of both major labor organizations have failed to comprehend the significance and potentialities of the craft-unit proviso of the New York act. ${ }^{49}$ If a craft-unit proviso were included in the Wagner Act, it would probably be invoked more frequently than has the New York proviso because of the greater proportion of manufacturing industries within the jurisdiction of the NLRB. But the New York experience indicates that the groups most

${ }^{47}$ The Charles Weisbecker case (SE-4563) is apparently the only case in which the craftunit proviso was employed by an AFL union in an attempt to obtain the exclusion of a small group of its members from a plant-wide unit which was represented by a CIO industrial union. This case was settled by an informal understanding between the parties. But cf. Great Atlantic \& Pacific Tea Co. (Decision No. II43-A, Dec. 3r, I940).

$4^{8} \mathrm{SE}-4682$, Decision No. 907 (June 5, I940).

At an informal conference in the Franklin Simon \& Co. case (SE-329o) the employer questioned the appropriateness of a craft unit of shoe salesmen, contending that if this unit were designated as appropriate, he would eventually be compelled to negotiate fifty-five separate contracts with the representatives of fifty-five separate units of its employees. The petition in this case was later withdrawn.

49 The AFL counsel, for example, appears to be unaware of the significance of the Saks decision. In reviewing the Report of the New York State Labor Relations Board, July I, x937 to December 3r, I939 (Albany, I940), which report contains (at p. I48) a quotation from the part of that decision quoted on page 486 above, Mr. Padway said: "By this positive provision of the law [the craft-union proviso, $\S 705(2)$ ] a subject of frequent dispute has been removed from controversy." 54 Harv. L. Rev. 720, 721 (I94I). 
vociferous in demanding this amendment to the Wagner Act would derive far less advantage from it than they now anticipate.

\section{BALLOTING TO DETERMTNE THE APPROPRIATE UNIT}

In the Globe case ${ }^{50}$ the NLRB declared that other considerations regarding the appropriate unit being evenly balanced, the determining factor should be the desires of the employees themselves. Consequently it directed separate elections in each of the skilled groups, the members of which were asked whether they desired to be represented by a craft union for their separate unit or by the industrial union seeking to represent all the employees of the plant in a single unit. Depending upon the vote of the majority, the members of each group would either constitute a separate appropriate unit or be included in the same industrial unit with the production employees. The latter were merely asked to indicate whether or not they desired to be represented by the industrial union. This procedure has been employed by the NLRB in subsequent cases in which all other considerations concerning the appropriate unit were evenly balanced and the record failed clearly to reveal the desires of the employees involved. The SLRB, on the other hand, has employed a different procedure. Although in only one case ${ }^{5 x}$ has it allowed a particular group of employees to vote directly on the question of whether or not they desired to bargain separately as a craft unit, in several cases it has asked certain employees to indicate whether or not they desired to bargain as a separate unit and secondly to indicate by which union they desired to be represented. This procedure may be interpreted as an attempt to carry out the legislative policy implicit in the craft-unit proviso..$^{52}$

The chief advantage of the SLRB procedure is that it can be employed in certain cases in which the Globe doctrine is inapplicable. In the Sachs Quality Furniture Co. case ${ }^{53}$ the Sachs Employees Association sought to represent in a single unit virtually all the employees of a department store. The United Office and Professional Workers of America (CIO) sought to represent the office and clerical employees as a separate unit,

so Globe Machine \& Stamping Co., 3 N.L.R.B. 294 (r937).

sz Great Atlantic \& Pacific Tea Co. (Decision No. II43-A, Dec. 3I, I940) at 24: "Butcher workmen .... constitute a craft within the meaning of Sec. 705 (2)."

52 In the determination of the appropriate unit the board has taken into account, among other factors, the following: the form and degree of organization and jurisdiction of the union, the nature of the work involved, the characteristics of the employers' business. Report of the New York Labor Relations Board, July I, I937 to December 3I, I939, at I38-69 (Albany, 1940).

s3 SE-17, Decision No. 39 (Dec. 17, 1937). 
but the SLRB denied it leave to intervene and refused to place its name on the ballot because it did not file its petition and charges within a reasonable time after the filing of the original petition by the Sachs Employees Association. The SLRB held two simultaneous elections in this case, the ballots given the clerical and office employees being divided into sections. Section " $A$ " contained the question: "Do you desire to bargain as a separate unit?" and section " $B$ " the question: "Do you desire to be represented by Sachs Employees Association?" The ballots for the warehouse, maintenance, and sales employees contained only the question: "Do you desire to be represented by Sachs Employees Association?"

Since the Globe doctrine requires employees in a certain group to choose between two or more unions advancing conflicting contentions with regard to the appropriate unit, it could not have aided the SLRB in the Sachs case, in which only one union was involved. Had the board directed a separate election to determine whether or not the office and clerical employees desired to be represented by the association, votes against the association cast because of lack of desire for collective bargaining would have been indistinguishable from those cast against the association because of a desire to bargain as a separate unit or because of opposition to representation by that particular union. In response to an inquiry by the CIO local shortly before the election, the board indicated that if the majority of the office and clerical employees voted to bargain as a separate unit and against representation by the Sachs Employees Association, it would immediately proceed on the basis of this local's petition to direct an election to determine whether or not the clerical and office employees desired to be represented by the local. Actually Io 7 votes were in favor of a separate unit and I37 against, while IO5 were against the Sachs Employees Association and I39 in favor. Thus of the votes in section "A" all but two were consistent with those in section "B." From these results it may be concluded that at least ro5 clerical and office employees desired to bargain as a separate unit to be represented by the CIO local. .5

54 In the Sachs case a second union was involved, although its name did not appear on the ballot; but in the case of Cadillac Motor Car Division of General Motors Sales Corp. (SE-3737, Decision No. 557, May 27, 1939) there was no contest whatsoever between unions. Here the employer contended that the testers and the stock clerks should not be included in the same unit with the shop employees. The board indicated that on the basis of a card comparison it would certify Local 259 of the UAWA (CIO) as the representative of the shop employees. It also directed two elections at which the testers and the stock clerks were to indicate whether or not they desired to be included in the same unit with the shop employees. These election results enabled the board to include the stock clerks and exclude the testers from the appropriate unit and to certify Local 259 as the representative of this unit. Obviously the Globe doctrine could not have been applied. 
Another type of case in which the SLRB procedure can reveal information unobtainable by application of the Globe doctrine is that in which a plant unit is challenged as inappropriate but neither union seeks to represent a particular group of employees as a separate unit. An example is the Buffalo General Laundries case, ${ }^{55}$ where the Federated Industrial Union, an unaffiliated organization, sought to represent all production and maintenance employees as a single unit while Local $I 7$ of the Laundry Workers International Union (AFL) contended that maintenance employees should not be in the same unit with the production employees it claimed to represent. Unable to determine the appropriate unit on the basis of the record, the SLRB ordered a preliminary election to determine whether or not the maintenance employees desired to bargain as a separate unit, ${ }^{56}$ the result being II to 8 in favor of bargaining as a separate unit. Here the Globe doctrine could not have determined the appropriate unit because the union seeking to represent the smaller group of maintenance employees was an industrial union which also sought to represent the production employees, while Local $\mathrm{x}$, which contended that maintenance and production employees should not be included in the same unit, claimed to represent only the production employees. The situation was precisely the reverse of that in the Globe case. An attempted application of the Globe doctrine would have allowed the maintenance employees to vote for or against Federated. But in counting the ballots cast against Federated the board could not have distinguished the votes of those desiring a separate unit from the votes of those who did not desire collective bargaining.

After the preliminary election Local I7 requested to be placed on the ballot at the second election to determine the bargaining representative of the maintenance employees. Sixteen of the maintenance employees voted for the Federated Industrial and two for Local I7; in a separate election among the production employees (held simultaneously) 2 I 8 voted for the Federated and 6 for Local I7. Since at the time of these later elections both unions sought to represent all of the employees in both units, there is little justification for the conclusion that a majority of the maintenance employees voted unintelligently and inconsistently for representation by an industrial union after having voted to bargain as a separate unit. At this stage there simply was no "craft" union in the field.

Although the SLRB procedure made it possible to obtain information concerning the desires of employees with respect to the bargaining unit unobtainable by use of the Globe doctrine, the information yielded in this and several other similar cases was of little practical value. There is no 
basis in law for the contention that certification of the Federated as representative for two separate units, the maintenance employees and the production employees, bound it to conduct separate negotiations and sign separate contracts for each unit, or for the assumption that there is legally a difference between two separate certifications and a certification as representative of a single unit. ${ }^{57}$ A contrary argument would imply that the board may regulate internal union affairs and would obviously be fraught with danger to the autonomy of labor organizations.

While the SLRB procedure is useful in cases where the Globe doctrine cannot be applied, in others the Globe doctrine would have obtained the necessary information more efficiently. In the Hearn Department Stores, Inc. case $^{58}$ a local of the Department Store Employees Union (CIO) petitioned for certification as representative of all but the supervisory employees of the company, while a local of the Wholesale Hardware, Crockery, and Housefurnishing Specialities Union (AFL) sought to represent the warehouse employees as a separate unit. On the basis of the record the board was unable to determine the appropriate unit. Relying on a card comparison it therefore certified the CIO local as the representative of the production employees and directed an election among the warehouse employees. Section "A" of the ballot asked the warehouse employees whether or not they desired to bargain collectively as a separate unit; section " $B$ " asked whether they desired to be represented by the CIO local or by the AFL local. Forty-one voted for a separate unit and 4 I against, while 56 voted for the CIO local and 25 for the AFL local. The board subsequently certified the CIO local as representative of all employees.

Since there was a clear-cut controversy concerning inclusion of the warehouse employees in the same unit with production employees, the Globe doctrine could have been applied simply by allowing the warehouse employees to choose between the CIO local and the AFL local. The procedure actually employed made it possible for at least I $_{5}$ warehouse employees to vote for bargaining as a separate unit and also to vote for representation by the CIO local, the industrial union. ${ }^{59}$ These

57 It should be noted that the Court of Appeals has ruled that an SLRB certification is not a final order. Wallach's, Inc. v. Boland, 277 N.Y. 345, I4 N.E. (2d) 38 I (I938). Of course the union may find it expedient to give the employees in the smaller unit separate representation on the bargaining committee, to negotiate a separate contract covering them, or to grant them some other special consideration in order to retain their loyalty.

${ }^{8}$ SE-976, Decision No. 288 (March 2I, I938).

59 Apparently one employee who voted for a separate unit failed to indicate any choice in section "B." 
contradictory votes were probably the result of a failure to comprehend the significance of a direct vote on the unit question or of confusion caused by the form of the ballot. Both might have been avoided by employment of the simpler Globe technique.

The possibility that employees will fail to understand a vote on the unit question is the major disadvantage of the SLRB procedure. It must be admitted, however, that employees have actually voted with a striking degree of consistency when the issue has been before them. Of the five cases in which sufficient evidence is available, in only two did more than 5 per cent and in none did more than I 5 per cent of the employees vote inconsistently. ${ }^{60}$ Another disadvantage is that the additional information yielded by this method is not always worth the added expense of the more complicated election procedure. This is certainly true of elections resulting in certification of the same union as representative of the employees in two separate units. On the other hand, the SLRB procedure does get to the heart of the controversy concerning the appropriate unit, and it minimizes the possibility that the central issue may be obscured by preferences and prejudices regarding the particular unions seeking to represent the employees. It is a democratic method of determining the appropriate unit in cases in which the Globe doctrine will not apply, either because no union seeks to represent one group of employees as a separate unit although it is not clear that these employees should be included in the same unit with the other employees, or because only one union is a party to the proceeding. The best policy for any labor board would be to apply the Globe doctrine whenever it can yield as much information as the SLRB procedure and to employ the SLRB procedure in all other cases. ${ }^{6 x}$

60 These two cases were Hearn's Department Stores (Decision No. I28, March I7, I938), and Consolidated Laundries (Decision No. 4, Sept. 29, r937). Virtually all of the employees voted consistently in the Int'I R. Co. (Decision No. 507, May II, 1939), Buffalo General Laundries (Decision No. 377, March 6, 1939), and Sachs Quality Furniture (Decision No. 39, Dec. I7, I937) cases. In the Int'l R. Co. case, II7 of the clerical and office employees voted to bargain in the same unit with the operating employees and 6 in favor of a separate unit, while II 7 voted for the Frontier Bus and Street Car Employees Union, which sought to represent all groups as a single unit, and 6 for the Transport Workers Union of America, Local 162 (CIO), which sought to represent the clerical and office employees as a separate unit. But in this case the fact that not a single employee voted inconsistently is largely attributable to the circumstance that the union which won the "toss" for choice of position on the ballot chose to have its name placed on the left of section "2" of the ballot, because the name of the unit which it sought was on the left side of section "r." It then instructed its adherents simply to place crosses in the two boxes on the left-hand side of the ballot.

6x The conclusions stated at this point in the text are those of Mr. Arenwald. Mr. Landay disagrees, believing that the SLRB procedure makes a spurious attempt to distinguish the unit 
THE "NEITHER" BALLOT AND RUN-OFE ELECTIONS

The problem of the general form of the ballot or ballots to be employed in representation cases involving two or more unions is one of the most difficult which confront a labor relations board. Should the voters be allowed to choose only between the two unions involved, or should they be permitted to indicate that they do not desire to be represented by any of these unions? If a majority vote for a union, but no single union obtains a majority of the votes, should the board conduct a second or run-off election, and if so, what form of ballot should be used? Or should it

from the union question. An employee often cannot separate the two questions: (a) which unit do you want? and (b) which union do you prefer? He may prefer a certain union irrespective of the unit it represents, and if required to express a preference on the unit question he would pick that unit which, on the basis of pre-election information, appeared most likely to lead to the designation of his favorite union. If, on the other hand, he preferred a unit in which no union sought to represent him, he might vote for the unit advocated by the union lest no union ever seek to represent him.

Such a situation actually did arise in an election among the employees of B. Altman \& Co., a large New York department store, where some clerks were given the usual two-section ballot asking if they preferred to bargain as a separate unit and, if not, whether they wished to be represented by the industrial union. SE-2659, Decision No. 296 (Jan. 26, I939). The notice of election informed them that if a majority voted for the separate unit no union would be certified as their representative. A majority voted for the industrial union, but the election does not show whether, as an abstract question without reference to any of the unions, that majority preferred the industrial unit. Consequently, a majority vote for a separate unit might have misled a "craft" union into supposing that the employees favored the craft form of organization when, as a matter of fact, their votes were entirely influenced by a dislike for the particular industrial union.

The Globe, in contrast to the SLRB ballot, does not ask the employee to make an artificial separation between the unit and union questions. He is asked to weigh carefully all the factors, including the appropriateness of the unit and the nature of the unions, before coming to his conclusion, which may be expressed by a single " $X$ " before the name of a union or of "no union." Thus far the NLRB has not extended the Globe doctrine to cases in which only one union seeks to represent the employees in all the different units. But this could readily be done by giving each group a chance to choose between the union in question and "no union." If this procedure had been used in the Sachs and Altman cases, for example, certain employees designated by the SLRB as constituting a possible separate unit would, like the rest of the employees, have received "Yes and No" ballots bearing the name of the industrial union. If a majority had voted "Yes," then they would be considered part of the industrial unit; if "No," then no union would be designated as their representative. While these employees would have to take into account the same factors as under the SLRB procedure, they would not be required to make a pretense at expressing a separate judgment on the unit and union questions. Fewer statistics would result, but so would less potentially misleading information.

Mr. Landay believes that the Globe doctrine should be extended by the NLRB to determine the appropriate unit when no union seeks to represent one group of employees even though it is not clear that these employees should be included in the same unit with the other employees, or when only one union is a party to the proceedings. The SLRB should also adopt this procedure, and both boards should reserve the present SLRB procedure for cases that cannot be resolved even by the Globe doctrine in its extended form. 
eliminate the possibility of a run-off by employing some form of preferential ballot?

Although originally the NLRB made no provision for a "neither" vote, and only the names of the competing unions were placed on the ballot, numerous requests for "neither" ballots ${ }^{62}$ early compelled the NLRB to face this issue. After having decided in the $R C A$ case $^{63}$ that eligible employees who abstained from voting would be deemed to acquiesce in the choice of the majority who voted, it realized the necessity of providing some method of indicating a desire for no collective bargaining. Consequently in the Interlake decision ${ }^{64}$ it initiated the policy of employing a "neither" ballot in elections involving more than one union.

The New York board did not realize the need for a "neither" ballot until about two years after the NLRB's Interlake decision. At the outset it followed the NLRB's original policy simply because at first none of the parties requested that a space for a "neither" vote appear on the ballot, and it maintained this policy even though the New York act, in contrast to the Wagner Act, expressly provides that representatives shall be selected "by a majority of the employees voting in an election." 65 Consequently, employees opposed to union representation would thwart the achievement of their own objective if they refrained from voting. In representation cases involving only one union, however, employees who did not desire collective bargaining could vote "No" on the question: "Do you desire to be represented by Union X?" Thus the mere fact that a second union sought to represent them was sufficient to deprive the employees of an opportunity to vote against representation by any union. The policy of the SLRB was made even more unjust by the fact that in a few cases in which the evidence indicated that only a bare majority of the eligible employees desired to be represented by a union, the SLRB directed, upon the affirmative request of one of the parties, that a space for "neither" be placed on the ballot. In three out of four of these cases the employer was the party making the request. These requests were granted despite the fact that implicit in the act is the notion that the em-

62 By a "neither" ballot is meant a ballot which includes a space in which the employees may indicate their desire to be represented by neither union.

63 Matter of RCA Mfg. Co., Inc., 2 N.L.R.B. 43 I (rg36).

${ }_{64}$ Matter of Interlake Iron Corp. 4 N.L.R.B. 55 (I937).

$65 \S 705(x)$ (italics added). The corresponding section of the Wagner Act ( $\$ 9 a)$ merely stipulates: "Representatives designated or selected for the purposes of collective bargaining by the majority of the employees in a unit appropriate for such purposes shall be the exclusive representatives of all the employees in such unit for the purposes of collective bargaining....." 
ployer should play no role in the determination of the union to represent his employees.

In the Daniel Reeves case, ${ }^{66}$ one of the first involving two unions, the employer requested a "neither" ballot, contending that nothing in the record showed that the two competing unions together represented more than a small minority of the employees. Although both unions opposed this request, the United Retail Employees of America (CIO) was unable to submit membership cards or other substantial evidence to support its contention that it represented a majority of the more than one thousand sales employees, while the other union, the American Federation of Grocery Store Employees (AFL) could submit only 230 cards, many undated. The board granted the request of the employer without comment, evading any careful consideration of its general policy with regard to the "neither" ballot.

The nature of the exception to the general rule expressed in the Reeves case was more clearly defined in the Aldar Realty Co. case. ${ }^{67}$ There the Building Employees Industrial Union (CIO), the petitioner, submitted application cards which allegedly had been signed by all the employees, and the Building Service Employees International Union (AFL) submitted cards alleged to have been signed by a majority of the employees. Nevertheless, the attorney for the employer formally requested that, in the event of an election, the board provide a space on the ballot for "neither." The board refused to grant this request because it found that in contrast to the Reeves case the evidence here clearly showed that nearly all the employees had expressed a desire to be represented by one or the other of the two unions, while nothing indicated that any of them did not desire to be represented by a union. The evidence for this decision consisted almost exclusively of membership cards; yet the board directed an election because it was unable to accept these same membership cards as sufficiently accurate indications of the desires of the employees to use them as the basis for certification.

The original policy of the SLRB was modified by its decision in the John Morrell and Co. case. ${ }^{68}$ The board granted a request by the employer for a "neither" ballot despite evidence that 34 of the 60 employees, or an actual majority, had indicated through membership applications a preference for one union or the other. The board based its decision on evidence consisting of application cards, which indicated that sixteen em-

\footnotetext{
${ }^{66}$ SE-916. Decision No. 134 A (April 15, 1938).

${ }^{67}$ SE-329, Decision No. 177 (June 17, 1938).

${ }^{68}$ SE-1204, Decision No. 29I (Jan. I2, I939).
} 
ployees had applied for membership in both unions, duplications which certainly tended to establish the unreliability of this evidence. Here, as in the previous cases, the board sidestepped consideration of the more general problems. ${ }^{69}$

In October, I939, the SLRB finally realized the injustice of its original policy and made a complete about-face. In a clearly reasoned decision, the SLRB stated in the Hotel St. George Corp. case ${ }^{70}$ that:

The Act likewise endows workers with equally complete freedom to refrain from such self-organization and to declare that such is the desire or preference of the majority. .... .

In elections in which two or more labor organizations lay claim to certification as exclusive collective bargaining representatives, the employees are entitled to express their desires on a ballot which will accord them precisely the same right they enjoy when a single union is concerned, i.e., to select one of the rival organizations to represent them or expressly to reject all these organizations. ${ }^{7 x}$

The board overruled the Aldar and Morrell decisions by rejecting the use of union membership cards as evidence for deciding whether or not to order a "neither" ballot. It explained:

Because, under the circumstances of this case, we could not accept these cards as final and unmistakable indications of the real desire of the employees, our first Direction of Election was issued. Similarly we are unable to accept the cards as an infallible indication of the number of employees who do not desire to be represented by the council or by Local $28.7^{2}$

In this important decision not only did the SLRB enunciate its present policy of providing an opportunity for a "neither" vote at all elections involving more than one union, but also it announced that where a majority of the employees voting favored a union, but no single union obtained a majority, it would order a run-off between the unions on the ground that the first election revealed a majority for collective bargaining.

This form of run-off election had previously been ordered in the Reeves case, where use of the "neither" ballot resulted in a majority of voters casting their ballot for one or the other of the two unions without either the CIO or AFL local obtaining a majority. The run-off procedure was unfavorably criticized by the CIO union and the company. The union contended that since the AFL local had received the smallest number of

¿9 Before October, I939, the SLRB also directed that a "neither" ballot be employed in the Cross \& Brown (SE-673, Decision No. 306, Dec. 19, 1938) and City Provision Co. (SE-709, Decision No. 384 , March 3,1939 ) cases. The latter was the only case in which the board did not order a "neither" ballot solely at the request of the employer.

${ }^{30} \mathrm{SE}-3353$.

${ }^{7 x}$ Decision No. 655-B (Oct. ro, I939).

72 Ibid. 
votes at the original election, it should have been eliminated from a further determination; the company contended that some who had voted for a given union might prefer no collective bargaining to representation by the rival union. Apparently the board was unable effectively to defend its plan in the face of this attack, for it withdrew its order for an immediate election. No run-off was ever conducted, for the case eventually died of old age.

In the Hotel St. George case the SLRB finally arrived at the "neither" ballot policy adopted about two years earlier by the NLRB in the Interlake case. On the other hand, not until five months after the Hotel St. George decision did the NLRB abandon its original policy, which merely allowed employees to indicate in a run-off election whether or not they desired to be represented by the union receiving a plurality at the original election, and adopt the SIRB's policy of a run-off between the two unions. ${ }^{73}$

The Hotel St. George decision assumes that a vote at the original election for either of the unions is an indication of a desire for collective bargaining through some representative. There may be cases in which interunion antipathy would cause a substantial number of the supporters of each union, if compelled to choose between the opposing union and no collective bargaining at all, to prefer the latter. But a policy allowing for this contingency would involve practical difficulties. The desires of the employees could then be accurately determined only by conducting two yes-or-no run-offs on the question of representation by each of the unions and then possibly a third run-off between the unions or alternatively by the use of a complete preferential ballot. The method of successive runoffs has obvious disadvantages. It would prolong the period of uncertainty and the strife accompanying the campaigns of competing unions. Extraneous factors might alter the desires of employees during the period of run-off elections. The union receiving the minority of the votes at its run-off might request a delay in order to regain prestige. And finally, the cost to the board and the parties of as many as four separate elections would be excessive.

The chief disadvantage of the complete preferential ballot is the likelihood of its degenerating into the ordinary type of multiple choice ballot if enough voters realize that refraining from indicating a second choice

${ }^{73}$ R. K. LeBlond Machine Tool Co. and Cincinnati Electric Tool Co., 22 N.L.R.B. No. I7 (I940). During the fall of I940, when the board lacked a chairman, this policy was continued because Dr. Leiserson, who has always opposed run-off elections, agreed to the practice "until that practice can be reconsidered by a three-member board." 27 N.L.R.B. No. I20 (1940). As of March I, I94I, no decision on this issue has been madesince Dr. Millis became chairman. 
will decrease the chance of any other group's obtaining a majority and increase the strength of their own first choice. ${ }^{74}$ Any attempt to compel indication of a second choice might create resentment and misunderstanding, leading to a large number of spoiled ballots. A second disadvantage is that the complexity of the method makes it more difficult for the workers to understand the mechanics of the election and thus diminishes the probability that they will accept the election results as decisive. Third, this method makes it possible for more than one union to obtain a combined total of first and second choices constituting a majority of the ballots cast and thus to claim certification.

If the present split in the labor movement did not render it politically inexpedient, both the NLRB and the SLRB might proceed on the assumption that employees who vote for a particular union would prefer representation by a competing union to no collective bargaining. The contrary assumption results in practical difficulties, and, moreover, there is evidence that the rank and file of the average labor organization do not hate a competing union as bitterly as do some of the leaders. A plan suggested by the authors based on this assumption would settle all issues in every case by a single election.

Let those voting for "neither" have the opportunity of expressing as their second choice a preference for one of the two unions in the event that a majority of the employees vote for collective bargaining. If the vote for the unions constitutes a majority but neither union obtains a majority, then only would the second choices of the "neither" voters be added to the respective totals of the two unions. Should this addition give one union an absolute majority, that union should be certified. It is possible, however, that many "neither" voters, either through lack of interest or because of a definite desire to do nothing to help a union, will refrain from indicating their second choices. Consequently even the second choices might not give either union a majority. In that event the board should certify that union which received a majority of the votes in favor of collective bargaining, that is, the union obtaining a plurality of all the votes. ${ }^{75}$ This plan would permit the "neither" voters to express a union preference if they desired but would not allow them to sabotage the election machinery by refusing to indicate a second choice. Moreover, under this plan it is impossible for more than one union to obtain a combined

74 Cf. Hoag and Hallett, Proportional Representation 489 (1926).

75 The "neither" ballots containing no indication of a second choice would merely have shown that less than a majority of those voting did not desire to be represented by either labor organization. 
total of first and second choices representing a majority of all the ballots cast. ${ }^{76}$ It is improbable, however, that the courts could reconcile certification of a union obtaining a plurality with the existing provision of the act that the board shall certify the representatives selected by the majority of the employees voting in an election.

An alternative plan, suggested by members of the SLRB staff and adopted by the parties in the Red Hook Houses case, ${ }^{77}$ could be more easily reconciled with this provision. On a two-part ballot, the employees were asked to vote in section " $\mathrm{A}$ " whether or not they desired to be represented by a union, and in section " $B$ " which of the two unions they preferred. The originators of this plan claimed that if a majority voted "Yes" in section "A," but the number of votes polled by the union which received a majority in section " $\mathrm{B}$ " was less than a majority of the votes cast in section "A," the board would be justified in certifying that union on the ground that there had been two separate elections and that the union had been selected by a majority of the employees voting in the second.

An advantage of this plan is that it places clearly before the employees the fundamental question of whether or not they desire collective bargaining. Moreover, if any voter, regardless of how he had voted in section "A," were permitted and encouraged to indicate a choice of representatives in section " $\mathrm{B}$," those desiring no collective bargaining could indicate their preference between the unions in the event that a majority voted for collective bargaining. Although the stipulation in the Red Hook Houses case does not indicate whether the board was to count the votes in section " $B$ " of those who voted against collective bargaining in section " $\mathrm{A}$," there is good reason for including them. The balloting having determined that there is to be collective bargaining, no voters should be deprived of an opportunity to join in selecting their representatives merely because of their primary preference for no collective bargaining. On the other hand, if, as in the Red Hook Houses case, a majority vote against collective bargaining in section " $\mathrm{A}$," the board may dismiss the petition without tallying the votes in section "B."

The disadvantages of this plan are: (I) that it increases the complexity of the election machinery ${ }^{78}$ and (2) that it makes the same questionable

${ }^{76}$ Since a minority have voted for "neither," the total number of second choices to be distributed must be a minority of the total ballots cast. No matter in what proportions this minority is distributed, only one of the two unions involved can be selected by a majority of the employees voting.

77 SE-2609. Since this was a consent election, the board did not decide the form of the ballot.

${ }^{78}$ By making it necessary to tally two sets of votes in every election involving more than one union in which a majority vote for collective bargaining. 
assumption that a vote for collective bargaining and for one union is still a vote for collective bargaining even though the other union may win the election. To circumvent the consequences of this assumption a union expecting defeat might request its adherents to vote for no collective bargaining in the first section of the ballot, in the hope that there would be sufficient other employees opposed to collective bargaining to prevent the "majority" union from being certified. In short, this scheme presupposes that the two sections of the ballot are separable in the voter's mind. It possesses no advantages over the ballot previously described except, perhaps, from the legal standpoint.

None of the schemes thus far discussed-the successive run-offs, the full preferential ballot, the ballot giving "neither" voters a choice of unions, or the Red Hook Houses ballot-is clearly legal either under the New York State Labor Relations Act ${ }^{79}$ or under the National Labor Relations Act. ${ }^{80}$ But assuming the law to be amended or otherwise modified, what election procedure or procedures should be authorized? ${ }^{8 x}$ There are really but two choices, because all the single elections proposed are essentially preferential ballots with restrictions on certain voters. One ballot, for example, permits indication of a second choice only by those whose first choice was "neither," and the Red Hook Houses ballot amounts in practice to the same thing. ${ }^{82}$ The run-off which eliminates the choice receiving the least votes differs from preferential balloting only in requiring a second election to determine the second choices.

In selecting a ballot form, it is clear that the procedure making the least assumptions as to an employee's choice is best. Since all the restricted ballots make some assumption as to the second choices of certain voters they are inferior in this respect to the full preferential ballot.

$79 \S 705(\mathrm{r})$.

80 \& ga as interpreted by the board in the RCA Mfg. Co. case, 2 N.L.R.B. 43 I (r936).

${ }^{8 x}$ Still another alternative has been urged by Dr. Leiserson in his dissenting opinions (Coos Bay Lumber Co., I6 N.L.R.B. 476 (I939), and the R. K. LeBlond Machine Tool Co., 22 N.L.R.B. No. I7 (I940) ): to close the case temporarily and to tell each union to request another election when it has won sufficient additional adherents to "make a prima facie showing that it is the designated representative of a majority of the employees." But this procedure would defeat one of the chief objectives of the Wagner Act: to substitute an election for the organizing strike, for to gain recognition as rapidly as possible one of the unions might call such a strike. Also the run-off or preferential ballot does not usually require an employee to transfer his allegiance from one union to the other (as Dr. Leiserson contends), but merely forces the "neither" voters to participate in selecting their collective bargaining representative.

${ }^{8 x}$ It is impossible for an employee to vote for a union as his first choice and for "no union" as his second. If union $\mathrm{X}$ is his first choice, he can mark his ballot consistently only by voting for collective bargaining in the " $A$ " section and for union $X$ in the " $B$ " section. There is no place for him to indicate an additional preference. 
On an unrestricted preferential ballot an employee can vote for one union and, as a second choice, for "no union."

While the run-off procedure is simpler than preferential voting, it has two serious disadvantages. It is much slower; at least a month elapses before the run-off election can be held, while the results of the preferential balloting take little if any longer to compute than those of the original election. Secondly, in the interim between the two elections the voters may change their minds in response to a "band wagon" effect, which is much more likely to appear in a labor than in a political election. In the latter a person's stand, even if it becomes known, is unlikely to affect him in a vital way, while his position in a union election, which he can hardly conceal from his fellow employees, may easily influence his employment opportunities. An employee has reason to know that by voting for the minority union he takes the risk that his grievances will be ignored by the victorious union. Only the necessity of educating employees in marking a preferential ballot should cause the NLRB to hesitate in adopting it. The SLRB should have little hesitancy in regard to elections held in New York City where two City Councils have already been elected by preferential balloting.

The operation of the New York State Labor Relations Act during its first three years has shown that granting to employers an extensive right to petition does not create unusually difficult administrative problems. It has shown that a craft-unit proviso does add a complex problem in the determination of the appropriate unit and is anything but advantageous to some organizations which have favored including it in the state and national acts. The SLRB has intelligently administered these provisions and has also pioneered in the development of valuable procedures for allowing employees to vote on the unit question and for run-off elections. 